\title{
A Critical Analysis of Judicial Appointment Process and Tenure of Constitutional Justice in Indonesia
}

\author{
Pan Mohamad Faiz \\ TC Beirne School of Law, the University of Queensland \\ The University of Queensland, St. Lucia Campus, Australia \\ Tel./Fax:+61-7-3365-2206 E-mail:pan.wijaya@uq.net.au
}

Submitted: May 26, 2016; Reviewed: Jul 14, 2016; Accepted: Jul 21, 2016

\begin{abstract}
The judicial appointment process is one of essential elements for maintaining judicial independence and public confidence of a court. This article analyses the practices of judicial appointment process exercised by three different main state institutions in selecting constitutional justice in Indonesia where the mechanism and process for selecting them have been implemented differently. It also examines the tenure of constitutional justice, which is a five-year term and can be renewed for one term only, that may lead to another problem concerning the reselection process of incumbent constitutional justices for their second term. The article concludes that the judicial appointment process and tenure of constitutional justice in Indonesia have to be improved. It suggests that if the proposing state institutions could not meet the principles of transparency, participation, objective and accountable required by the Constitutional Court Law, the judicial appointment process should be conducted by creating an independent Selection Committee or establishing a cooperation with the Judicial Commission. Additionally, the tenure of constitutional justices should also be revised for a unrenewable term with a longer period of nine or twelve years.
\end{abstract}

Keywords: Constitutional Court; Constitutional Justice; Judicial Appointment; Tenure DOI: http://dx.doi.org/10.20956/halrev.v1n2.301

\section{INTRODUCTION}

James J. Spigelman, the Chief Justice of New South Wales, argues that there is no single model of judicial appointment applicable in every system of judiciary. ${ }^{1}$ However, it is believed that judicial appointment process plays an important role to maintain

James Jacob Spigelman. (2007). "Judicial Appointments and Judicial Independence", paper presented at the Rule of Law Conference, Brisbane, August 31, p. 16. judicial independence and public confidence of a court. It also has an influence on the impartiality, integrity and independence of judges. ${ }^{2}$ Based on Article 24C(3) of the In-

\footnotetext{
See, for example, Sarkar Ali Akkas. (2004). "Appointment of Judges: a Key Issue of Judicial Independence". Bond Law Review, 16(2): 200-201; Constitution Committee. (2012). Twenty-Fifth Report: Judicial Appointments. The House of Lords of the United Kingdom. Available from: http://www.publications.parliament. uk/pa/ld201012/ldselect/ldconst/272/27205.htm. [Accessed May 11, 2016]; United States Institute of Peace. (2009). Judicial Appointments and Judicial Independence. Available from: http://www.usip.org/sites/de-
} 
donesian Constitution, the Constitutional Court (Mahkamah Konstitusi, or MK) has nine constitutional justices nominated by the president, the People Representative Council (Dewan Perwakilan Rakyat, or DPR) and the Supreme Court (Mahkamah Agung, or MA). The number of constitutional justices and its selection model is identical to the system implemented in South Korea. Harding and Leyland named this selection model the Korean representative. ${ }^{3}$ This model establishes an ideal check and balance mechanism among constitutional justices in which the executive, the legislative and the judiciary branches of government select nine constitutional justices.

The advantage of this selection model is that it can build and share trust between the three branches of government because they directly participate in selecting and determining constitutional justices. In addition, the selected constitutional justices have stronger political legitimacy compared to the selection model determined by a single branch of government. For example, if the president or the DPR appoints all constitutional court justices, the two other branches of government may criticise their choices or blame them if the Constitutional Court performs poorly.

fault/files/Judicial-Appointments-EN.pdf.[Accessed May 11, 2016].

Andrew Harding and Penelope Leyland. "The Constitutional Courts of Thailand and Indonesia: Two Case Studies from South East Asia" in Andrew Harding and Penelope Leyland (eds). (2009). Constitutional Courts: A Comparative Study. London: Wildy, Simmonds \& Hill Publishing, p. 329.
Moreover, many cases handled by the Court are closely linked to political and constitutional issues, thus political legitimacy is required. The selection model determined by three different branches of government is also believed to generate constitutional justices from different backgrounds, deemed advantageous in deciding various constitutional cases. This selection model of constitutional justice is acceptable, in theory. However, this practice for selecting constitutional justices has many problems. The main cause being that the three branches of government do not have the same mechanism in selecting constitutional justices. The Constitutional Court Law only regulates some general provisions relating to the nomination and selection procedure of the constitutional justices:

Article 19:

The nomination of constitutional justices is conducted transparently and participatory.

Article 20:

(1) The procedure for selection, election and submission of constitutional justices are regulated by the respective authorised institutions as referred in Article 18(1).

(2) Selection of constitutional justices referred in paragraph (1) shall be conducted objectively and accountably.

The question is how to improve the judicial appointment process for selecting constitutional justice in Indonesia in order to strenghten judicial independence and public confidence of the Constitutional Court? In this article, I will start by examining constitutional justice selection practices in 
each branch of government holding power to select candidates. The weaknesses of the current selection mechanism are analysed in order to improve the system. Given that the selection mechanism of constitutional justices is closely related with its tenure, this article will also examines the current provision concerning the tenure or term of office of constitutional justices.

\section{ANALYSIS AND DISCUSSION}

\section{Judicial Appointment Process}

As explained above, the judicial appointment process for selecting constitutional justice received criticsm because the three branches of goverment do not implement the same mechanism. This section will analyse those practices in order to improve the judicial appointment process.

\section{Analysis on Practices of Constitutional Justice Selection}

The practice of constitutional justice selections conducted by each branch of government has received frequent criticism. First, there were inconsistent procedures for selecting constitutional justices by the president. In selecting the second generation of constitutional justices, President Susilo Bambang Yudhoyono, well known as President SBY, formed an independent Selection Committee in 2008. This Committee publicly announced candidate registration for constitutional justices. They also invited various legal and constitutional experts to be candidates. After a series of screening and assessment, the Selection Committee nominated the best candidates to be appointed by President SBY.

Nevertheless, when selecting Patrialis Akbar as a constitutional justice and extending the tenure of Constitutional Justice Maria Indrati for a second term in 2013, President SBY did not form an independent Selection Committee. ${ }^{4}$ Rather, the selection process was conducted internally, without public participation. This led to public suspicion that the President chose his people for the sake of personal interest. Several NGO activists, known as the Civil Society Coalition to Save the Constitutional Court, disapproved of the selection process and filled a lawsuit with the Administrative Court against the President's decision. They argued that the selection violated the principles of transparency, participation, objectivity and accountability, as required by the Constitutional Court Law. ${ }^{5}$

Surprisingly, the Jakarta Administrative Court granted the petition and annulled Presidential Decree Number 87/P of 2013 on the Appointment of Patrialis Akbar and Maria Farida Indrati. ${ }^{6}$ However, the President SBY and Patrialis Akbar appealed to the Ja-

Patrialis Akbar was a member of the People Representative Council of the National Mandate Party (20042009) and Minister of Justice and Human Rights under the President SBY (2009-2011). Previously, Akbar ran as a candidate for Constitutional Justice in 2009 through the DPR, but he was not selected by his colleagues in the DPR Law Commission.

5 Ina Parlina. (2013). "Administrative Court Strips Patrialis of MK Seat". The Jakarta Post, December 24. Available from: http://www.thejakartapost.com/ news/2013/12/24/administrative-court-strips-patrialismk-seat.html -0. [Accessed March 10, 2016].

6 See Jakarta Administrative Court Decision No. 139/G/2013/PTUN-JKT. 
karta High Administrative Court. A year later the Court accepted their application, ${ }^{7}$ yet the Coalition appealed to the Supreme Court. In 5 February 2015, the Supreme Court rejected the Coaltion's application. ${ }^{8}$ Thus, Akbar and Indrati continue to serve as Constitutional Justices. Furthermore, after the change of national leadership, from President SBY to newly elected President Joko Widodo, known as Jokowi, an independent Selection Committee was re-established to conduct the fourth generation selection process of constitutional justices, as Jokowi's administration did not want to make the same mistake as his predecessor.

Second, the Supreme Court only selected candidates who have served as judges for balancing the composition and expertise of constitutional justices. However, the Supreme Court's selection process was relatively closed. It is often criticised because the selection process lacked transparency and did not fulfil the participatory principles mandated by the Constitutional Court Law. Although the Supreme Court gave the public an opportunity to provide information on candidates' track records, the public had never known how the Supreme Court would use that information.

Furthermore, the Supreme Court appears reluctant to encourage their justices to be constitutional justices in the Constitutional Court. Up to the present, only one Su-

\footnotetext{
See Jakarta High Administrative Court Decision No. 55/B/2014/PT.TUN.JKT

8 See Supreme Court Decision No. 495 K/TUN/2014.
}

preme Court Justice has been selected to be a constitutional justice, namely Laica Marzuki (2003-2008). In consequence, many people have questioned the Supreme Court's consideration in selecting Constitutional Justices. The most reasonable argument for this is that not many Supreme Court Justices and judges are interested in becoming constitutional court justices. There is also little possibility that the Supreme Court wants their best justices to work for the Constitutional Court because the Supreme Court still need their expertise in deciding thousands of pending cases. ${ }^{9}$ Additionally, it seems that institutional competition exists between the Supreme Court and the Constitutional Court. As the oldest court in Indonesia, the Supreme Court, established in 1945, want to have a better a reputation than the Constitutional Court. In my view, the Supreme Court prefers to strengthen its own institution rather than strengthen another institution by sending their best justices and judges.

Third, the DPR selection process of constitutional justices is considered the most transparent. The DPR provided a wide opportunity for anyone to register as a candidate. They also held a formal interview for all candidates. This selection process was covered directly by various mass media, including a live broadcast from national television stations. However, the selection process

\footnotetext{
For a comparison, the Supreme Court of Thailand always sends their best judges to be Constitutional Court Justices. One of its reasons is that the Chief Justice of the Constitutional Court of Thailand has to be selected among judges sent by the Supreme Court. See Harding and Leyland, Op. Cit., p. 329.
} 
by the DPR also receives sharp criticism for being largely influenced by political party affiliation owned by the candidates. In addition, candidates often lobby DPR members. According to the confession of the former Chief Justice Mahfud MD, he lobbied DPR Law Commission members to be selected as a Constitutional Justice. ${ }^{10}$ As of today, four out of five Chief Justices of the Constitutional Court have been selected by the DPR. ${ }^{11}$ Three of them were political party officials, while the remaining two were academics in Constitutional Law. ${ }^{12}$

Nonetheless, it cannot be concluded that the constitutional justices give special advantage to the DPR's interests, despite being selected by the DPR. In fact, they actually contributed to the revoking of various laws made by the DPR. Furthermore, there is no empirical evidence to date that they favour their political party affiliations in deciding electoral disputes. However,

10 Rita T Budiarti. (2013). Kontroversi Mahfud MD [The Controversy of Mahfud MD]. Jakarta: Konpress, pp. 53-58.

11 The Chief Justice and the Deputy Chief Justice of the Constitutional Court are selected from and by the constitutional justices. At time of this writing, the former Chief Justices were Jimly Asshiddiqie (2003-2008), Mohammad Mahfud MD(2008-2013), M. Akil Mochtar (2013) and Hamdan Zoelva (2013-2015), while the current Chief Justice is Arief Hidayat (2015-Present). Zoelva is the only former Chief Justice who was selected by the President.

12 Jimly Asshiddiqie is a prominent Professor of Constitutional Law at the University of Indonesia; Mahfud MD was a National Awakening Party (PKB) official and a member of the DPR (2004-2008) as well as a Professor of Constitutional Law at the Islamic University of Indonesia in Yogyakarta; Akil Mochtar was a Golkar Party official and a member of the DPR (1999-2008); Hamdan Zoelva was a Crescent Star Party (PBB) official and a member of the DPR (1999-2004); and Arief Hidayat is a Professor of Constitutional Law at the University of Diponegoro. legal experts consider constitutional justices who have been members of a political party tend to make decisions deemed more political than academic. ${ }^{13}$ In this context, the main concern is about the independence of the Constitutional Court. The constitutional justices with backgrounds as politicians are more likely to be approached during the decision-making process by political parties or others people involved in the inner circle of political parties.

During the leadership of Chief Justice Mahfud MD such a concern was not proven; however, when ChiefJusticeAkil Mochtarled the Constitutional Court, the independence of the Court was highly questionable. Mochtar was caught red-handed by the Corruption Eradication Commission (KPK) in his home on 2 October 2013 for allegations related to accepting bribes from political party officials in handling electoral cases in several regions. ${ }^{14}$ This shameful arrest immediately destroyed public trust towards the Constitutional Court. Many litigants in the Constitutional Court questioned various decisions made by Akil Mochtar, particularly in disputes on regional head elections. The DPR who selected Mochtar as

13 See Setara Institute. (2013). Laporan Survey Persepsi 200 Ahli Tata Negara terhadap Kinerja Mahkamah Konstitusi RI [Report on Survey of Perception from 200 Constitutional Law Experts concerning the Performance of the Constitutional Court]. Jakarta: Setara Institute, p. 6.

14 P J Leo. (2013). "MK Chief Justice, Golkar Lawmaker arrested for Bribery Charges'. The Jakarta Post, October 3. Available from: http://www.thejakartapost.com/ news/2013/10/03/mk-chief-justice-golkar-lawmakerarrested-bribery-charges.html. [Accessed March 10, 2016]. 
a Constitutional Court Justice also received criticism from the public. They also asked the DPR to take responsibility for their decision in extending Mochtar's tenure for a second term (2013-2018). Mochtar's tenure had been extended by the DPR on February 2013, eight months before his arrest.

In response to such criticism, the DPR conducted an internal evaluation of the selection mechanism for constitutional justices. In selecting the fourth generation of constitutional justices in 2014, the DPR, for the first time, established the Expert Team of the Constitutional Justices Selection consisting of academics and national figures. The DPR then selected the candidates who were only nominated by the Expert Team. ${ }^{15}$ This new mechanism was undertaken by the DPR to restore public trust in the DPR and the Constitutional Court.

\section{Improving the Selection Mechanism}

Many people are concerned the selection mechanism of constitutional justices does not meet the principles stipulated by the Constitutional Court Law, which are that it be transparent, participatory, objective and accountable. As suggested by James J. Spigelman, the process of selection must also be administered fairly, rationally, predictably, consistently and impartially. ${ }^{16}$ Critics of the practice of constitutional justice se-

\footnotetext{
15 Margareth S Aritonang. (2014). "Lawmakers Defend Their Choice of MK Justices". The Jakarta Post, March 7. Available from: http://www.thejakartapost.com/ news/2014/03/07/lawmakers-defend-their-choice-mkjustices.html. [Accessed May 16, 2016].

16 Spigelman, Op. Cit., p. 17.
}

lections culminated after the arrest of Chief Justice Akil Mochtar. ${ }^{17}$ Public trust fell drastically. All praise given by the public to the Court vanished immediately. The public are increasingly distrustful of law enforcement in Indonesia due to the collapse of the last bastion to seek justice in the Constitutional Court.

To evaluate this situation, on 5 October 2013 President SBY gathered the leaders of all high state institutions, excluding the Constitutional Court, asking for inputs in creating an Interim Emergency Law to save the Constitutional Court. ${ }^{18}$ The Constitutional Court was disappointed because they were not invited to attend or be involved in the meeting. ${ }^{19}$ Two weeks after the meeting, President SBY issued an Interim Emergency Law containing several fundamental revisions on the Constitutional Court Law with an intention to improve the selection mechanism as well as the supervisory system of constitutional justices. ${ }^{20}$

17 Haeril Halim. (2015). The Jakarta Corruption Court sentenced former Chief Justice Akil Mochtar to life in prison. The Jakarta High Court and the Supreme Court strengthened this sentence after passing the appeal process. See "Akil Set for Move to Bandung Prison". The Jakarta Post, March 12. Available from: http://www. thejakartapost.com/news/2015/03/12/akil-set-movebandung-prison.html. [Accessed May 16, 2016].

18 Sandro Gatra. (2013). "Bahas MK, Presiden Kumpulkan Pemimpin Lembaga Negara [Discussing the Constitutional Court, the President Gathers the Leaders of High State Institutions]". Kompas, October 4. Available from: http://nasional.kompas.com/read/2013/10/04/2251552/ Bahas.MK.Presiden.Kumpulkan. Pemimpin.Lembaga. Tinggi.Negara. [Accessed May 16, 2016].

19 Harry Susilo. (2013). "MK Kecewa Tak Dilibatkan Presiden [Constitutional Court is Disappointed not to be Involved by the President]". Kompas, October 6. Available from: http://nasional.kompas.com/read/ 2013/10/06/0819211/MK.Kecewa.Tak.Dilibatkan. Presiden. [Accessed May 16, 2016].

20 Government Regulation in Lieu of Law No. 1 of 2013 on the Second Amendment to Law Number 24 of 2003 
The main revisions are: (1) It adds a new requirement for candidates of constitutional justices that they shall not be members of any political party within a period of at least seven years prior to the nomination; ${ }^{21}$ (2) The Expert Panel will be established by the Judicial Commission to conduct a fit and proper test for all candidates of constitutional justices. They will propose candidates who pass the fit and proper test to the president, the DPR and the Supreme Court, ${ }^{22}$ and (3) The Constitutional Court and the Judicial Commission will establish the Honorary Council of Constitutional Justices with a main task of enforcing the Code of Ethics and Code of Conduct of Constitutional Justices. $^{23}$

However, not everyone agreed on the President's decision in declaring the Interim Emergency Law. Several academics and NGO activists filed a constitutional review with the Constitutional Court. During the court proceedings, the Interim Emergency Law was approved by the DPR to be enacted into a new Law. ${ }^{24}$ In its decision, however,

on the Constitutional Court (hereinafter the Interim Emergency Law on the Constitutional Court).

21 Article 15(2)(i) of the Interim Emergency Law on the Constitutional Court.

22 The Expert Panel had seven members consisting of one person nominated by the Supreme Court, one person nominated by the DPR, one person nominated by the president and four people selected by the Judicial Commission. See Article 18A, Article 18B, and Article 18C of the Interim Emergency Law on the Constitutional Court.

23 The Honorary Council of Constitutional Justice had five members consisting of one former Constitutional Justice, one legal practitioner, two academics with legal background and one community leader. See Article 27A of the Interim Emergency Law on the Constitutional Court.

24 Law Number 4 of 2014 on The Enactment of Government Regulation in Lieu of Law Number 1 of 2013 on the Constitutional Court revoked the new Law entirely using the following main arguments.

First, the Constitutional Court reasoned that the nomination of constitutional justices, through the Expert Panel established by the Judicial Commission, reduced the constitutional powers granted by the Constitution to the President, the DPR and the Supreme Court. Furthermore, the Expert Panel will select constitutional justices with the same standards, including similar background. The Court stated that selected constitutional justices should have different backgrounds because they originally come from three different branches of government. According to the Court, favouritism and populism should be avoided in the selection of constitutional justices. ${ }^{25}$

Second, the Constitutional Court said that the Judicial Commission is not a supervisory body of the constitutional justices. ${ }^{26}$ The Court considered the involvement of the Judicial Commission in the recruitment process and the supervision of constitutional justices to be a form of 'smuggling of law' (fraudem legis). ${ }^{27}$

Third, the Court reasoned that the additional requirement for constitutional justhe Second Amendment to Law Number 24 of 2003 on the Constitutional Court (hereinafter the Enactment of Interim Emergency Law on the Constitutional Court).

25 Constitutional Court Decision Number 1-2/PUUXII/2014, reviewing Law No. 4 of 2014 on the Enactment of Government in Lieu of Law on the Constitutional Court Law (MK Pеrppu (2014) case), pp. 110-111.

26 See Constitutional Court Decision No. 005/PUUIV/2006, reviewing Law No. 22 of 2004 on Judicial Commission (Judicial Commission (2006) case).

27 Ibid., p. 115. 
tice candidates, to not be a member of any political party at least seven years prior nomination, negatively stigmatises political party members. According to the Court, such stigmatisation injures the citizens' constitutional rights as guaranteed by the Constitution because it lacks a solid and valid legal basis. ${ }^{28}$ Fourth, the Constitutional Court found that the Interim Emergency Law on the Constitutional Court did not meet the constitutional requirements of emergency circumstances or a state of necessity according to the Constitution and the Constitutional Court decision. ${ }^{29}$ As a result, the Constitutional Court entirely annulled the Law. Given that it was an unpopular decision, the Court received a lot of criticism from the public.

The question remains: how should the selection mechanism of constitutional justices be improved? In my view, based on the evaluation of the past twelve years, the selection of constitutional justices can still use the model, the so-called Korean representative, ${ }^{30}$ where each branch of government has a power to select three constitutional justices.

28 Ibid., p. 116. This argument received sharp criticism because it is not consistent with another Constitutional Court decision stating that the candidates for the Election Commission members should have resigned from their membership of political parties at least five years to the self-nomination of candidates. The Court created this additional requirement in order to maintain the independence of the Election Commission members from political parties. See Constitutional Court Decision Number 81/PUU-IX/2011, reviewing Law No. 15 of 2011 on General Election Organiser (KPU and DKPP Members (2011) case).

29 Ibid., pp. 118-120. For discussion on the requirements for determining emergency circumstances, see also Constitutional Court Decision Number 138/ PUU-VII/2009, reviewing Perppu No. 4 of 2009 on the Amendment of Law No. 30 of 2002 on Corruption Eradication Commission (KPK Pеrppu (2009) case).

30 Harding and Leyland, Op. Cit., p. 329
At this stage, as a new judicial institution with strategic roles, the Indonesian Constitutional Court still needs support and political legitimacy from other state institutions, particularly the president, the DPR and the Supreme Court. Thus, shared responsibility from the three state institutions towards the performance of the Constitutional Court is required since they all contribute in selecting constitutional justices. In addition, the Constitutional Court has become the midpoint for implementing checks and balances within the constitutional system in Indonesia.

Nevertheless, a main weakness of this model is the possibility of candidates being selected as constitutional justices who lack expertise and competencies, but may have strong personal relationships with the President, the DPR Law Commission members or the Chief Justice of the Supreme Court. This type of constitutional justice selection is motivated by efforts to secure the interests of the nominating state institutions.

Moreover, there is also a concern that ordinary candidates will intentionally be selected by the nominating institutions to weaken the Constitutional Court performances, known as 'the Trojan horse strategy'. There are several suggestions to avoid or at least to minimise these weaknesses of the current constitutional justice selection mechanism.

First, each branch of government must create specific and permanent procedures for selecting constitutional justice candidates. 
This procedure can be regulated internally. Without a clear mechanism and procedure, however, the selection of constitutional justices may change every time depending on the interest of nominating institutions. The establishment of an Independent Selection Committee or an Expert Panel by the President and the DPR should be continued as an initiative from the respective state institutions. This establishment is needed to avoid the subjectivity of decisions made by the President, the DPR Law Commission members and/or the Chief Justice of the Supreme Court.

Second, the President, the DPR and the Supreme Court can cooperate formally with the Judicial Commission. These three state institutions can ask for assistance from the Judicial Commission, as the Selection Committee, to nominate the best candidates for constitutional justices. A formal cooperation like this would not conflict with the Constitution or the Constitutional Court decision because it would be based on the respective state institutions delegating some of their power to the Judicial Commission. However, the final decision to select the constitutional justices would remain in the hands of each state institution, since the Judicial Commission only nominates the candidates of constitutional justices. In addition, the President and the DPR have previously agreed to establish the Expert Panel for the Judicial Commission, as stated in the Interim Emergency Law on the Constitutional Court.
It has also received input from the Supreme Court during the consultative meeting between the president and other state institutions. Therefore, if the three state institutions remain consistent in their decisions and recommendations, there is no reason for these institutions to reject the involvement of the Judicial Commission or an Independent Selection Committee for nominating constitutional justices.

Third, another frequent problem in the selection process is that there are too few candidates interested or considered worthy to be selected as constitutional justices. Therefore, the Selection Committee or the Expert Panel should be more active in inviting and searching for candidates. Presently, many legal and constitutional experts are not interested in registering themselves, due to the political lobbying practiced in the selection process. With the establishment of an Independent Selection Committee or an Expert Panel free from political intervention, it is expected that more constitutional justice candidates, with different expertise, will be interested in registering themselves, or being registered by others. It will be easier for state institutions to select nominated candidates when the number of qualified registrants increases.

\section{Tenure of Constitutional Justices}

The tenure or term of office of Constitutional Court Justices also raises a polemic in the reselection process of the incumbent con- 
stitutional justices. According Article 22 of the Constitutional Court Law, the tenure of a constitutional justice is five years and can be renewed for one term only. ${ }^{31}$ A problem occurs when an incumbent, including the Chief Justice of the Constitutional Court, is to be reselected for their second term. Should they register and follow the fit and proper test again with other new candidates? The absence of clear provisions in the Constitutional Court Law has resulted in each branch of government implementing their own procedures for reselecting the incumbent constitutional justices. The following section analyses the problems caused by the tenure and reselection mechanism of constitutional justices.

\section{Problems of Tenure and Reselection Mech- anism}

At the end of his tenure, Chief Justice Jimly Asshiddiqie (2003-2008) was not interested in extending his position for a second term because he would have to reapply and follow the selection process from the beginning, again. However, the professionalism and progressiveness showed during his leadership lent credibility and trustworthiness to the Constitutional Court. In this case, according to Asshiddiqie, it was unethical for constitutional justices to register themselves for a second term

31 Based on Article 15 and Article 23 of Law No. 8 of 2011 on Amendment of the Constitutional Court Law, a candidate of constitutional justice must meet at least 47 years of age or maximum 67 years of age at the time of appointment and he/she retires after reaching 70 years of age. because because at the same time they still had to handle many cases. Nevertheless, he agreed his tenure to be extended on the condition that he would not have to apply or follow the fit and proper test. ${ }^{32}$ Finally, the DPR created a special procedure to nominate Asshiddiqie; as a result, he was reselected without taking a fit and proper test. ${ }^{33}$

After the 2008-2013 leadership periods, Chief Justice Mahfud MD decided not to continue to his second term. The main reason was because Mahfud, who was a former member of the DPR from the Partai Kebangkitan Bangsa (PKB), had a desire to be a presidential or vice presidential candidate in the 2014 Presidential Election. ${ }^{34}$ Furthermore, Akil Mochtar, who became the third Chief Justice of the Constitutional Court, continued his second term after being reselected by the DPR. Mochtar also rece-

32 Ali S Harahap. (2008). "Beralasan Menjaga Etika, Jimly Emoh Melamar ke DPR [Reasoned to Maintain the Ethics, Jimly does not want to apply to the DPR]". (2008). Hukum Online, February 18. Available from: http://www.hukumonline.com/berita/baca/hol18569/ beralasan-menjaga-etika--jimly-iemohi-mela-mar-kedpr. [Accessed March 18, 2016].

33 Jimly decided to resign from his position as a Constitutional Justice just one month after he was reselected for the second term (2008-2013). Jimly reasoned that he had completed his duty to establish the Constitutional Court during its first five years. Nevertheless, a strong argument is that Jimly's resignation was due to him not being reselected as the Chief Justice. In close voting among the Constitutional Justices, Jimly was defeated by his colleague Mahfud MD, 5:4 votes. In addition, Jimly's resignation was also taken to avoid the emergence of leadership disharmony in the Constitutional Court.

34 Although Mahfud MD had been campaigning seriously, and he helped the National Awakening Party (PKB) increase their seats in the DPR, Mahfud was not nominated as a candidate for President or Vice President by any political party, including PKB. Mahfud just became the Head of Campaign Team for Presidential Candidate Prabowo Subianto, who was defeated by his opponent Joko Widodo in the 2014 Presidential Election. 
ived a special procedure from the DPR to bypass any fit and proper test. The DPR only asked if he would be willing to be reselected as a constitutional justice for the period of 2013-2018.

Fourth Chief Justice Zoelva's selection, by President SBY, followed a different procedure for his reappointment. If he would like to continue his second term in 2015 , the newly elected President Jokowi would need to reselect him. In selecting a new constitutional justice, as discussed previously, President Jokowi formed a Selection Committee in order to fulfil the selection principles mandated by the Constitutional Court Law. The Selection Committee announced that incumbent Chief Justice Zoelva still had to register himself, or be registered by others, to be a candidate for constitutional justice. There was also an obligation for him to follow all selection processes without any distinction from other candidates. These selection processes consisted of administrative selection, assessment of track record and an open interview by the Committee and the public.

The decision taken by the Selection Committee was different from the previous selection process and cannot be separated from public concern caused by the arrest of previous Chief Justice Mochtar. Although Zoelva was registered by human rights NGOs, such as the Impartial and the Indonesian Legal Aid Foundation, he decided not to follow the selection processes and left the decision about his second tenure to President
Jokowi. Given that Hamdan did not have a public interview, the Selection Committee could not nominate him as a constitutional justice candidate to be selected by President Jokowi. ${ }^{35}$

Zoelva argued that, ethically, a constitutional justice, particularly the Chief Justice of the Constitutional Court, did not need to reapply and follow the fit and proper test again in order to assess his feasibility as a constitutional justice candidate. In an interview on national television, Zoelva said that the President and the Selection Committee only needed to assess his performance and track record during his first tenure as the Chief Justice or a Constitutional Justice. From that assessment, according Zoelva, the President or the Selection Committee could decide whether he should continue his term or not, without following another fit and proper test. Zoelva also argued that his decision was taken to maintain the dignity and the honour of the Constitutional Court. Many people regretted that Zoelva's tenure

\footnotetext{
35 President Jokowi finally selected I Dewa Gede Palguna, a former Constitutional Justice from the first generation (2003-2008) and a law lecturer at Faculty of Law of the University of Udayana in Bali. Palguna is also a former member of Group Delegates (Utusan Golongan) of the People's Consultative Assembly (MPR) proposed by the Bali Provincial DPR (1999-2004). Together with Hamdan Zoleva and Patrialis Akbar, Palguna involved in the Ad-Hoc Committee III during the process of the 1945 Constitutional amendment and the establishment of the Constitutional Court. Given that the Group Delegates was abolished in 1999, Palguna chose to join the Indonesian Democratic Party-Struggle (PDI-P) because the Party won almost $80 \%$ of votes in Bali at the time. PDIP-P is the party where President Jokowi becomes one of its members. However, Palguna assured that he would be independent from any political party, including from the PDI-P, as shown when he was serving as a Constitutional Justice under the leadership of Chief Justice Jimly Asshiddiqe (2003-2008).
} 
was not extended since he had greatly contributed in leading the Constitutional Court, restoring public trust during the critical period after Mochtar's case, particularly when he led the Constitutional Court in resolving hundreds of cases concerning legislative and presidential elections disputes in 2014. Hamdan compared this treatment to the two former Constitutional Court Justices, Jimly Asshiddiqie and Akil Mochtar, who were reselected by the DPR without taking any fit and proper test.

Furthermore, other Constitutional Justices were reselected for their second term by the President and the Supreme Court through direct personal interviews only. For instance, President SBY reselected Abdul Mukthie Fajar (2003-2008), as a Constitutional Justice, for a second term (2008-2010) through a personal interview. Likewise, President SBY also reselected Maria Farida Indrati (20082013) for a second period (2013-2018) without a fit and proper test. In addition, the Supreme Court reselected Maruarar Siahaan (2003-2008; 2008-2010), Muhammad Alim (2008-2013; 2013-2018) and Anwar Usman (2011-2016; 2016-2021) for second terms without undertaking a reselection process.

Moreover, Constitutional Justice Harjono, who was selected by President Megawati for his first term (2003-2008), could be reselected by the DPR for the second term (2009-2014), replacing Asshiddiqie who resigned from his position. Harjono was only asked about his willingness to be nominated as a candidate for constitutional justice by the DPR without having to follow any fit and proper test. However, the decision to select Harjono followed the voting mechanism of the DPR Law Commission members.

At the time of writing, the only Constitutional Justice who followed another fit and proper test, but was not reselected, was Ahmad Fadlil Sumadi from the Supreme Court. This decision attracted public attention because Sumadi was a strong candidate for a second term. Additionally, the Judicial Commission also recommended Ahmad Fadlil Sumadi as one of two Constitutional Justices that should be selected by the Supreme Court. ${ }^{36}$ Nevertheless, the Supreme Court selected other candidates. ${ }^{37}$ Some suggested that Sumadi was not reselected because he often made decisions that were unfavourable to the Supreme Court, the state institution who had selected him. Another possible reason is that Sumadi, who is a Judge of the Religious High Court in Yogyakarta, had served too long in the Constitutional Court. Before becoming a Constitutional Justice (2009-2015), he was the Chief Registrar of the Constitutional Court from 2003 to 2008. Thus, Sumadi had worked for ten years in

36 Ali S Harahap. (2014). "Tak Loloskan Ahmad Fadlil, Pansel MA Dikritik [Not Selecting Ahmad Fadlil, the Selection Committee of the Supreme Court was criticised]". Hukum Online, December 3. Available online from: http://www.hukumonline.com/berita/baca/ 1t547f267df25f2/tak-loloskan-ahmad-fadlil--panselma-dikritik. [Accessed March 18, 2016].

37 The Supreme Court decided to select Suhartoyo, a Judge in the High Court of Denpasar, and Manahan MP Sitompul, the Deputy Chairman of the High Court of Bangka Belitung, to be Constitutional Justices from 2015 to 2020 replacing Ahmad Fadlil Sumadi and Muhammad Alim. 
the Constitutional Court, equal to two terms of a constitutional justice's tenure.

\section{Revising the Tenure of a Constitutional Justice}

Based on the discussion above, it is clear that a problem exists regarding the constitutional justice tenure and the mechanism to reselect the incumbent constitutional justices. In my view, the incumbent constitutional justices should be invited and asked whether they are willing to continue their term or not. They should not have to follow another fit and proper test again, let alone be asked directly about every decision they have ever made. Incumbent candidates can be assessed through their integrity, capability and independence during their tenure as constitutional justices. An examination can also be conducted on legal opinions and legal considerations made by the incumbent candidates in their Constitutional Court decisions. The selection process should also follow the principles contained in the Constitutional Court Law which are transparency, participation, objectivity and accountability.

Nonetheless, it does not mean that all incumbent constitutional justices would be automatically reselected. If the assessment result is not good, then their tenure does not need to be extended. The Selection Committee then can begin looking for new constitutional justice candidates. This suggestion is a form of the compromise mechanism between the interests of the Selection Committee and the ethical issues faced by the Chief
Justice or constitutional justices who will be assessed for their second term. However, this mechanism should be regulated by revising the Constitutional Court Law or by making an internal regulation in each nominating institution.

However, the best improvement is not exactly related to the mechanism and procedure for reselecting incumbent constitutional justices. In my view, reforms should relate to the tenure of constitutional justices, set up as a five-year term and able to be renewed for another term. One reason to limit a term to five-years is to adjust to the five-year political cycle of presidential and legislative elections. This system exists because constitutional justices are considered as political representatives of their nominating institutions. Therefore, if the performance of a constitutional justice is not in accordance with the interests of the proposing institution, they will not be reselected.

In this context, constitutional justices are vulnerable to the interventions of proposing institutions seeking to secure their own interests. Therefore, the provision concerning a constitutional justice's tenure should be revised for once and not renewed. However, ideally, tenure has to be longer than five years. There are several supporting arguments for revising this tenure.

First, the impending expiration of tenure can potentially reduce the independence of constitutional justices since, to be reselected, they may make decisions deemed more 
Table 1. Comparison on Tenure of Constitutional Court Justice

\begin{tabular}{lclcc}
\hline \multicolumn{1}{c}{ Country } & Institutions & Tenure & Non-Renewable & Renewable \\
\hline Austria & Constitutional Court & Lifetime & - & - \\
Belgium & Constitutional Court & Lifetime & - & - \\
Germany & Federal Constitutional Court & 12 years & $\sqrt{ }$ & \\
Russia & Constitutional Court & 12 years & $\sqrt{ }$ & \\
South Africa & Constitutional Court & 12 years & $\sqrt{ }$ \\
Turkey & Constitutional Court & 12 years & $\sqrt{ }$ \\
Czech Republic & Constitutional Court & 10 years & & $\sqrt{ }$ \\
Bulgaria & Constitutional Council & 9 years & $\sqrt{ }$ \\
France & Constitutional Council & 9 years & $\sqrt{ }$ \\
Italy & Constitutional Court & 9 years & $\sqrt{ }$ \\
Lithuania & Constitutional Court & 9 years & $\sqrt{ }$ \\
Morocco & Constitutional Court & 9 years & $\sqrt{ }$ & \\
Poland & Constitutional Tribunal & 9 years & $\sqrt{ }$ \\
Portugal & Constitutional Court & 9 years & $\sqrt{ }$ \\
Romania & Constitutional Court & 9 years & $\sqrt{ }$ \\
Spain & Constitutional Court & 9 years & $\sqrt{ }$ \\
Thailand & Constitutional Court & 9 years & $\sqrt{ }$ \\
Ukraine & Constitutional Court & 9 years & $\sqrt{ }$ \\
Colombia & Constitutional Court & 8 years & $\sqrt{ }$ \\
Croatia & Constitutional Court & 8 years & $\sqrt{ }$ \\
Mongolia & Constitutional Court & 6 years & & \\
South Korea & Constitutional Court & 6 years & & \\
\hline
\end{tabular}

Source: Compiled by the author.

acceptable and in line with the interests of proposing institutions. Second, the presence of periodisation has clearly caused problems for constitutional justices who uphold their ethics. Therefore, removal of periodisation would make the constitutional justice selection process easier. Third, a five-year period is too short for a new constitutional justice who has important complex constitutional cases. In addition, it takes time for a new constitutional justice to adapt for handling and formulating decisions rationally and accountably.

Fourth, at the stage where Indonesian constitutionalism develops rapidly, however, the tenure of constitutional justices should not last a lifetime, but should be restricted to a limited time and retirement age. This system would be in line with the principles of the
Constitution as a living document, where the perspectives and thoughts of constitutional justices in interpreting the Constitution need to be developed. A study conducted by Abhinav Chandrachud suggests that the independence of judge is not dependent on the length of terms, but it is influenced by other factors, such as an apolitical judicial appointments process and structural security of tenure..$^{38}$

Fifth, the five-year term created by the Indonesian Constitutional Court is one of the shortest constitutional justice's tenure in the world. Consequently, it is vulnerable to intervention from the changing political cycle. In this case, using a comparative

\footnotetext{
38 Abhinav Chandrachud. (2013). "Does Life Tenure Make Judges more Independent? A comparative study of Judicial Appointments in India". Connecticut Journal of International Law, 28(2): 316-317.
} 
study form other constitutional courts, as showed on the Table 1 above, I suggest that the tenure of constitutional justices should be nine to twelve years and non-renewable.

Lastly, the tenure of the Chief Justice and the Deputy Chief Justice, which are only two and a half years, should also be revised. The current system proved problematic during the leadership transition from Chief Justice Jimly Asshiddiqie to Chief Justice Mahfud MD, leading to the resignation of Asshiddiqie as a constitutional justice. Therefore, the tenure of the Chief Justice and the Deputy Chief Justice should finish at the end of his or her tenure as a constitutional justice. Thus, there would be no internal conflict among the constitutional justices who want to compete for the position of the Chief Justice or the Deputy of Chief Justice of the Constitutional Court. Moreover, the position of the Chief Justice and the Deputy of Chief Justice is a noble position, a symbol of Court leadership and court management. Therefore, it should not be frequently rotated among constitutional justices.

\section{CONCLUSION}

After twelve years since its establishment, the Indonesian Constitutional Court still faces many institutional challenges. This article shows a serious challenge faced by the Indonesian Constitutional Court related to the recruitment system for selecting constitutional justices. There was inconsistency in determining the selection mechanism since each proposing institution lacked a specific and permanent procedure to select constitutional justices. Moreover, criticism of the selection mechanism of constitutional justices often happened because the judicial appointment processes were deemed not transparent, participatory, objective or accountable, as required by the Constitutional Court Law principles. In this context, the state institutions that have a power to select constitutional justices are the president, the DPR, and the Supreme Court, and they must implement these principles. If they cannot meet the principles, they have to establish an independent Selection Committee that free from any intervention. Alternatively, the proposing state institutions can cooperate with the Judicial Commission to nominate the best candidates for constitutional justices.

Furthermore, the reselection mechanism of the incumbent Chief Justice or the constitutional justices for their second term created a problem because it was done differently among the proposing state institutions. In resolving this problem, the tenure of constitutional justices should be revised. Currently, the Constitutional Court Justices hold a position for five years and their tenure may be renewed for one term only. In my view, the constitutional justices should serve for one term only for a period of nine or twelve years. This means the constitutional justices will have a longer tenure, yet it is unrenewable. The term of the Chief Justice and the Deputy Chief Justice, which is only two and 
a half years, should also be revised. Ideally, the Chief Justice's term should end at the completion of his or her tenure as a constitutional justice, while the Deputy Chief Justice may be promoted to be the Chief Justice. In addition, the position for the Chief Justice should not be alternately chaired because it can cause internal conflict.

Finally, the improvements concerning judicial appointment process and tenure of constitutional justice in Indonesia can strengthen the independence of constitutional justices so they will not be dependent upon the proposing state institution when making decisions. Indeed, the improvements can also increase public confidence of the Constitutional Court.

\section{BIBLIOGRAPHY}

Abhinav Chandrachud. (2013). "Does Life Tenure Make Judges more Independent? A Comparative Study of Judicial Appointments in India". Connecticut Journal of International Law, 28(2): 297-318.

Ali S. Harahap. (2008). "Beralasan Menjaga Etika, Jimly Emoh Melamar ke DPR [Reasoned to Maintain the Ethics, Jimly does not want to apply to the DPR]". Hukum Online, February 18. Available from: http://www.hukumonline.com/ berita/baca/hol18569/ beralasan-menjaga-etika--jimly-iemohi-melamar-kedpr. [Accessed March 18, 2016].

Ali S Harahap. (2014). “Tak Loloskan Ah- mad Fadlil, Pansel MA Dikritik [Not Selecting Ahmad Fadlil, the Selection Committee of the Supreme Court was criticised]". (2014). Hukum Online, December 3. Available from: http:// www.hukumonline.com/berita/baca/ 1t547f267df25f2/tak-loloskan-ahmadfadlil--pansel-ma-dikritik. [Accessed March 18, 2016].

Andrew Harding and Penelope Leyland. "The Constitutional Courts of Thailand and Indonesia: Two Case Studies from South East Asia" in Andrew Harding and Penelope Leyland (eds). (2009). Constitutional Courts: A Comparative Study. London: Wildy, Simmonds \& Hill Publishing.

Constitution Committee. (2012). TwentyFifth Report: Judicial Appointments. The House of Lords of the United Kingdom. Available from: http:// www.publications.parliament.uk/pa/ ld201012/ldselect/ldconst/272/27205. htm. [Accessed May 11, 2016].

Constitutional Court Decision No. 005/ PUU-IV/2006, reviewing Law No. 22 of 2004 on Judicial Commission (Judicial Commission (2006) case).

Constitutional Court Decision Number 138/ PUU-VII/2009, reviewing Perppu No. 4 of 2009 on the Amendment of Law No. 30 of 2002 on Corruption Eradication Commission (KPK Perppu (2009) case).

Constitutional Court Decision Number 81/ 
PUU-IX/2011, reviewing Law No. 15 of 2011 on General Election Organiser (KPU and DKPP Members (2011) case).

Constitutional Court Decision Number 1-2/ PUU-XII/2014, reviewing Law No. 4 of 2014 on the Enactment of Government in Lieu of Law on the Constitutional Court Law (MK Pеrppu (2014) case).

Haeril Halim. (2015). "Akil Set for Move to Bandung Prison". (2015). The Jakarta Post, March 12. Available from: http://www.thejakartapost.com/ news/2015/03/12/akil-set-move-bandung-prison.html. [Accessed May 16, 2016].

Harry Susilo. (2013). "MK Kecewa Tak Dilibatkan Presiden [Constitutional Court was Disappointed not to be Involved by the President]". Kompas, October 6. Available from: http://nasional.kompas.com/read/2013/10/06/0819211/ MK.Kecewa.Tak. Dilibatkan. Presiden. [Accessed May 16, 2016].

Ina Parlina. (2013). "Administrative Court Strips Patrialis of MK Seat". The Jakarta Post, December 24. Available from: http://www.thejakartapost.com/ news/2013/12/24/administrativecourt-strips-patrialis-mk-seat.html-0. [Accessed March 10, 2016].

Indonesia. Government Regulation in Lieu of Law No. 1 of 2013 on the Second Amendment to Law Number 24 of
2003 on the Constitutional Court.

Indonesia. Law Number 24 of 2003 on the Constitutional Court.

Indonesia. Law Number 8 of 2011 on Amendment of Law Number 24 of 2003 on the Constitutional Court.

Indonesia. Law Number 4 of 2014 on The Enactment of Government Regulation in Lieu of Law Number 1 of 2013 on the Second Amendment to Law Number 24 of 2003 on the Constitutional Court.

Indonesia. The 1945 Constitution.

Jakarta Administrative Court Decision No. 139/G/2013/PTUN-JKT.

Jakarta High Administrative Court Decision No. 55/B/2014/PT.TUN.JKT.

James Jacob Spigelman. (2007). “Judicial Appointments and Judicial Independence", paper presented at the Rule of Law Conference, Brisbane, August 31. Margareth S. Aritonang. (2014). "Lawmakers Defend Their Choice of MK Justices". The Jakarta Post, March 7. Available from: http://www.thejakartapost.com/news/ 2014/03/07/lawmakers-defend-their-choice-mk-justices.html. [Accessed May 16, 2016].

P J Leo. (2013). “MK Chief Justice, Golkar Lawmaker arrested for Bribery Charges". (2013). The Jakarta Post, October 3. Available from: http://www.thejakartapost.com/ news/2013/10/03/mkchief-justice-golkar-lawmaker-arrested-bribery-charges.html. [Accessed 
March 10, 2016].

Rita T. Budiarti. (2013). Kontroversi Mahfud $M D$ [The Controversy of Mahfud MD]. Jakarta: Konpress.

Sandro Gatra. (2013). "Bahas MK, Presiden Kumpulkan Pemimpin Lembaga Negara”. Kompas, October 4. Available from: http://nasional.kompas. com/read/2013/10/04/2251552/Bahas. MK.Presiden.Kumpulkan.Pemimpin. Lembaga.Tinggi.Negara. [Accessed May 16, 2016].

Sarkar A. Akkas. (2004). "Appointment of Judges: a Key Issue of Judicial Independence". Bond Law Review, 16(2): 200-210.
Setara Institute. (2013). Laporan Survey Persepsi 200 Ahli Tata Negara terhadap Kinerja Mahkamah Konstitusi $R I$ [Report on Survey of Perception from 200 Constitutional Law Experts concerning the Performance of the Constitutional Court]. Jakarta: Setara Institute.

Supreme Court Decision No. 495 K/TUN/ 2014.

United States Institute of Peace. (2009). Judicial Appointments and Judicial Independence. Available from: http:// www.usip.org/sites/default/files/Judicial-Appointments-EN.pdf. [Accessed May 11, 2016]. 